\title{
ETHICS OF ENTERTAINING MEDIA CONTENT
}

\begin{abstract}
Entertainment media content attracts the attention of younger as well as older audiences. The authors examine the ethical principles that apply to entertainment media content and wonder what is ethically problematic in entertaining content and where to draw the line. The paper also analyzes the codes of ethics of European countries in order to determine whether there are specific provisions for entertaining media content. In the second part of the paper, the results of a survey conducted at the Faculty of Philosophy in Niš are presented with the aim of determining whether young people recognize violations of ethical principles in entertainment media contents. Also, the results reflects the attitudes of students in terms of paying attention to the unethical content of these media - whether ethical violations hurt their dignity and whether they feel deceived.
\end{abstract}

Key words: ethic principles, media, students, entertainment program, code of journalism ethics

\section{Introduction}

Since its very beginning, the media has been misused by various entities. The ethical problems that soon arose concerned authentic reporting, censorship and objectivity. The opportunity to reach out to a large audience gave "wings" to all those whose job demanded propaganda - politicians, the military, the church, business owners, marketers. In order to secure their position, protect society and the profession itself, journalists have formed ethical associations and compiled codes of ethics.

Ethics can be considered as a higher instance of morality because it gives legitimacy to moral foundations. Professional ethics is a set of obligations that regulates certain practices and arises from morality. Journalism ethics is determined by the relationship of moral obligations that the journalist has as a citizen and as a journalist. The main difference between these two types of ethics is that in journalism ethics decision making is rational, that is, it uses arguments, while professional ethics is rather a set of written rules (Babić, 2000). The basic principle of journalism ethics is authenticity. Relevance is also one of the most important principles, in addition to fairness and objectivity.

However, when it comes to entertainment, these principles are ignored. Entertainment content is subject to ethical judgment. On the other hand,

\footnotetext{
${ }^{1}$ Received September 2019 / Accepted May 2020

${ }^{2}$ E-mail: dojchaaa@gmail.com
} 
entertaining media content is treated differently because of its nature and easily accepted by people. However, the effects of entertaining contents are great - from influencing the formation of attitudes in young people, through inciting violence and encouraging behavior models, to dumbing down children and adults. The paper focuses on entertainment media content ethics, presenting the functions of mass media communication, then is given a brief overview of Codes of Ethics worldwide and in Serbia, it has been discussed about the ethical problem in the context of infotainment journalism and entertaining media content. Further in the paper also has been examined whether European codes of ethics contains provisions regarding the entertaining media content, and at the end it has been shown the results of a survey on the attitude of young people about the ethics of entertainment content and their recognition of unethical entertainment content.

\subsection{Functions of mass communications}

We can say that the functions of communication are one of the reasons why journalists publish irrelevant news. The notion of relevant news refers to news that is relevant to the public. Journalists are obliged to publish exactly this kind of news. In this way, they make life easier for society and individuals who are unable to obtain all the information that would make their existence easier, and one of the reasons for that is that ordinary citizens are not in that position. An ordinary citizen simply cannot verify a lot of information, hence the distrust of the media and the need for information (Bernays, 2014). On the other hand, it is the journalist who in the name of the public can get information that an ordinary individual cannot.

In addition to intrapersonal, personal and group communication taking place among people, communicologists also distinguish mass communication, which involves the press, radio, television and the Internet. Although with the advent of mass media, the mode of communication is different from face-to-face communication, the motives, intentions and goals are largely the same as in communication without the mediation of mass media. L. Manovič has shown in his papers that the Internet did not move far from television by its principle of operation, and concluded that the new media are not entirely new media (Manovič, 2001). We agree with Manovič that this is the case when we talk about the Old/New media difference. When we talk about the everyday/media communication difference, it seems that the difference is only in the mode of communication, but that the motives are the same. "Communication processes between the media and the public began to be seen as complex interactions with unpredictable effects." (Cvetanović, 2018:95) These unpredictable effects, among other things, relate to audience and media interactivity, an opportunity created with the emergence of new media.

Communication can be regarded as instrumental - which means that communication serves as a means of obtaining information, decision-making, or as a means of entertainment. "Instrumental communication is a strategic activity," says Janićijević (Janićijević, 2006:24). The four basic functions of communication are the following: 


\section{1. informative \\ 2. entertaining \\ 3. instructive \\ 4. persuasive (2006:24).}

These functions of communication are also found in journalism. The goal of the journalist is to inform, entertain and instruct. Persuasion is an accompanying function used by all media with the aim of being the most watched (television, internet), most read (press, internet), or most listened to (radio). Public communication consists of different news, from political to weather forecast. Janićijević believes that the media can provide us with objective information, free of attitude. However, objectivity is difficult to achieve. As for entertainment, which is becoming more present in serious shows, but above all a faithful companion of educational shows for children and adults, we believe that this function of communication is very important. It has its positive sides: humor, profoundness, stress relief, sparking new interests, or new world views, etc. It is negative: when entertainment trivializes some social problems and situations, if it is vulgar, if it offends certain social groups, especially those vulnerable, if it incites violence, etc. Instruction involves teaching. Teaching means explanation. "There is almost no situation or informative, entertaining and persuasive communication that does not have an educational value for a person seeking knowledge or some skill," said Janićijević (2006: 27). Persuading is considered the most complex function.

Today, the commercial media is full of fake photos and false news, especially about public figures. There is a thin line between falsehood and sensationalism, but both are unethical ways of reporting on people. The consequences of this kind of reporting are generally bad. A public figure being subject to falsehood may suffer, as well as their family, and the public is usually subject to deceit. Misinformation is one of the most widespread ways to deceive the public. It can often be found on news portals or social networks, either in the form of fake news or fake commenters such as bots or fake sources. Theorists distinguish several types of fake news: Satirical news; Parodies; Fabricated news; Visual manipulations; Propaganda Content; Advertising content (Baraković, 2019:62).

\section{Review of first principles of Journalism Ethics}

The first principles of journalism ethics are found in the French newspaper Gazzete De France of 1631. It was founded by Theophrast Renaudot, who wrote the following in the preface: “... prevents the spread of many false rumors that often serve as tinder for negative development and discord in the country," (Corney, 1999). However, normative ethics in the form of professional rules began to emerge only in the nineteenth century, also in France, where professional associations emerged and the freedom of the press was discussed. The first codes were created in the XX century: in Sweden in 1923, in Finland in 1924, in Norway in 1936, in Great Britain in 1938, in Italy in 1928, in America in 1923, in Serbia after World War II, etc. 
The first codes and commissions against the exploitation of violence, sex and bloodshed were established in Hollywood under the pressure of Protestants and conservatives, between the 1930s and 1960s. This code applied to movies, and a movie could hardly be distributed unless it had the MPAA (Motion Picture Association of America) seal confirming the compliance with the Code. The contents of the Hays Code were very conservative and restrictive. The Hays Code prohibited the display of nudity, even silhouettes, couples of different races, childbirth scenes, and the mention of sexually transmitted diseases. The display of violence, killing, torture or anything that would cause horror was prohibited. Television must not develop an interest in gambling, and ridicule the law; crime must not be justified or presented as profitable; criminal techniques will not be portrayed as instructive (Bertrand, 2007: 68).

The second Code is the Code of Good Conduct adopted in 1929. Since this Code was found to violate antitrust laws, it was replaced by the Declaration of Principles in 1990. This Code has made a major impact on large networks and the behavior of the entertainment industry. This Code prescribes the pursuit of creativity and change, as well as positive effect on morality. It is very important to encourage social and cultural diversity.

The third code is the internal code of the CBS network.

The Hutchins Commission is known in the United States, under the chairmanship of Robert Maynard Hutchins (a former rector of the University of Chicago), which in 1947 submitted a report attributing special responsibility to the media as organizations.

It should be noted that "ethical issues are not entirely reducible to what occurs in and through screened program. They also extend to, or wholly emerge from, what lies behind and what comes with or after distribution, promotion, and transmission, thus exhibiting extra/and intertextual dimension." (Mast, 2016:2181).

In Europe, the Scandinavian countries (Sweden, Court of Honor in 1916, Code in 1923), Finland (Freedom of the Press Act in 1919, Code in 1924), Norway (Code in 1936) were first to get their codes. In Serbia, in 1881, at the founding assembly of the Serbian Journalists' Association, the request was "to protect the reputation and interests of journalism by assembling a jury of honor for each member who would compromise the freedom of the press in Serbia by misusing the public word." After the Second World War, the Serbian Journalists' Association improved its normative acts and the Journalists' Code of Ethics.

\section{Ethical problems of entertaining media content}

Contemporary journalism is colored by sensational reporting and tabloid approach to information. The media has been particularly criticized for content that is inappropriate for young people, children, and the elderly; then for content that undermines cultural values and trivializes reality. The ethical problems behind these criticisms are: terrifying content (massacres, murders, fights, etc.), obscene content (sex, etc.), religious programs 
(verbal and physical violence, disrespect for human dignity) etc. Sensationalism is also present in serious journalism; however, the media that cross the line are at risk of becoming semi-tabloids or tabloids. The topic of this research is the ethics of entertainment media contents. By entertainment media contents we mean commercial media content, but also the content of the public service intended to entertain the audience.

We can say that each medium has its own entertainment program, and that it often instrumentalizes entertainment to gain a growing audience. For example, William Hearst, the owner of Sunday, the first tabloid newspaper, realized that it was very useful for a newspaper to include a comic (The Yellow Kid); the television program is becoming vulgarly entertaining and unified, the radio uses modern technologies and posts photos that accompany the news on social media, online media use interesting headlines to influence the audience to click on them and to make them more profitable. The entertaining role of the media, explains Bertrand (2007) also has its therapeutic function because pure reality is harsh.

Commercial program is omnipresent in the media, and profit has become the main goal of media organizations. Editors' favorite imperatives are the following: Be the first! Be original! Be different! Be the most present and most wanted! And lastly, be favorite! This is often in conflict with professionalism and ethics; therefore, violations of codes of ethics are very common.

Entertainment media ethics is different from informative media ethics. It is certain that it cannot be the same for both sectors; for example, fictional characters, advocating a stand, and fictional dialogues correspond to some historical drama but not news. (Bertrand, 2007: 65)

Bertrand (2007) notes that there are no codes drawn up by people from show business, which is strange because public relations companies, as well as advertisers, and many other professions have professional codes. Diversity of content is cited as the reason for the lack of codes in show business. Much content, e.g. sports, can be classified as both entertaining and informative. People watch sports as a hobby, out of curiosity or as a professional duty. Different contexts influence whether it is entertainment or something else. If it is a hobby, sport is undoubtedly entertainment, but neither curiosity nor professional duty exclude entertainment. Also, shows like knowledge quizzes are educational and entertaining, and television channels such as National Geographic, Animal Planet and others are almost always entertaining.

Commercial media are characterized by aesthetic mediocrity. They rarely promote creativity in the fields of fine arts, classical music, literature, philosophy, etc. Huge production brings big profit to media owners, but it hinders social development, notes Bertrand (2007). Another accusation against the media is that they do not stimulate thinking. Thus, the media audience is often referred to as passive. The media bombard us with information; information comes so fast that it is impossible to think twice about the same thing; plus plenty of manipulation techniques that make most of what the media provide seem accurate, correct and truthful. Second, we often use the media in moments of boredom and leisure, so it seems to us that there is no need to be bothered with problems of ethics and similar. 
The ethical problem of the media is often associated with the question: what values do the media provide? Good people in movies, TV series, and reality shows have stopped being winners a long time ago. The media create new heroes: selfish, mean, conservative or eccentric. A real hero has all anti-values - intolerant, greedy, addicted to material things, and a raw representative of their nation.

The media are pushing the trend of irrational buying and consumption, which should be continuous and represents a kind of shopping research in which buyers or consumers observe, collect and systematize their products, and then by the "like/ dislike" method reject some and predict the trend for next season for the remaining products. (Gonsalo, 2012).

Moderation and measures are long gone as the values of the world represented by the media. Violence, speed, noise, bloodshed - these are the values of the virtual world in which the minority that believes in true values and presents them is swallowed up.

\section{Infotainment and ethics}

Employees of modern media systems more than ever use the entertainment function of the media to achieve win in every segment of the audience. In the era of digital journalism, in which the media market is flooded by informations, while media channels are saturated with an abundance of information, it is "necessary" to attract the attention of the audience and insinuate to them by giving finely wrapped informations in "infotainment ${ }^{3}$ cellophane".

„If so many commercial and political interests invest so much money in media advertising, it is absurd to believe that the media has no influence on our behavior. Otherwise, billions of dollars were wasted by advertisers." (Dej, 2008: 230)

An entertaining TV program can often be in function of the Agenda setting theory, while the broadcasting of an entertaining program is in the function of diverting attention from essential problems. Contemporary media rely on technical-discursive elements of the program (broadcast graphics, graphical logo, visual elements), as well as the sitting arrangement in the studio, while paying attention to the furniture and the entire studio mise-en-scène, in order to create an image for the viewers of more informal, relaxed and natural way of chating about important topics. Almost as if these TV program is being played in the viewer's living room. Graphical-visual elements are also accompanied by the substantively-structural way in which the news is processed and presented to the audience. Thus, news broadcasts have evolved into informative talk shows (eg. "150 minuta" or "Jutro sa Jovanom i Srđanom" on Prva TV in Serbia), in which the news program is based on interesting television reports, while the interviewees from the TV reports are often guests in the studio. The principles that apply to tabloid journalism in the press apply with slight convergence modifications onto television journalism.

\footnotetext{
${ }^{3}$ Infotainment journalism is a term coined from the English words "information" and "entertainment" and means an information program designed according to the principles applicable to entertainment and commercial broadcasts.
} 
„The basic distinction between quality print media and tabloids rests on a different approach to information material (information), which in reputable journalism is expected to respond to three basic requirements: actuality, relevanceimportance and interestingness. (...) In the tabloid editorial approach, the topic selection process is reversed: it rests on the third form of information." (Todorović, 2006: 22)

The dominant media ideology of the 21st century is the ideology of market capitalism, in which news are treated as a commodity and the audience as an interest and target group. According to the process of glocalization, media conglomerates are imposing new trends, while "few large companies have power over production, distribution and exposure globally, which accelerates the homogenization of world society in the interest of commercialism" (Tjurou, 2012:314). Observing the dominant discourse of television expression, one concludes that age of consumerism imposed by the industrial age of the media has led to the marginalization of real, investigative journalism. Quality journalism retreats in the face of trivialization of public sphere. The taste of the audience „must be" satisfied at any costs, starting with the viewers need to replace the gloomy picture of everyday life with cheerful and spiritually empty programs, in which consumers will give their counscience under concession to editors and journalists. In this regard are Neda Todorovic's words about consequences of consuming tabloid news, which reflects on the formation of the reader's image of the world, on the processes of creating public opinion, on the encouragement and maintenance of unhealthy voyeurism that replaces reality with false, virtual reality. (Todorović, 2006: 29). An eclectic example of the stated is TV show, „Paparazzo lov“, which airs on Serbian television "Pink“, in which journalists and camera crew follow celebrities in their daily lives, and often make vulgar comments, while the audience is pleased by normality of untouchable TV stars.

The popularity of entertainment media content stems from moments of leisure, in which the average TV viewer simply wants to relax, while the mesmerizing power of television easily draws him into his fictitious world, where is a thin line between entertainment and disrespect of the Code of ethics. A good illustration for stated is that the reality show "Zadruga" received its special TV channels (Zadruga 1, Zadruga 2, Zadruga 3) on the IPTV operator of Telekom Srbija. As misleading as it may be, it may be that the separation of entertainment and entertainment programs can be a solution for further media perspective, and that is broadcasting such and similar programs on separate TV channels, thus, the status of national television stations which have undeservedly received this frequency - will be resolved. In this regard, Stanko Crnobrnja points out that in the world of commercial television, with its status as a popular (populist) entertainment, there is indeed an unwritten rule that television programs should not be researched as "serious" (critical) analysis, because this program is so simple as it is, namely simplified, that there is literally nothing in it that should be analyzed in this serious way. (Crnobrnja, 2010: 15)

One of the main challenges facing REM is the fair distribution of television ether on state and commercial-private channels. Precisely, because media is not 
ethically and meaningfully distributed, we have a current situation where, in prime time period, national televisons broadcast and propagate an obscure and vulgar program through a reality show program culture. Easy entertainment in the form of reality shows and soap operas certainly does not contribute to the television audience's spiritualization, although media, and above all, television technology, has incredible potential for cultivating audience. That is why it is especially important for the audience to be able to recognize the influence of the media, but also to ask why a particular media program is broadcasted at a certain time, at a time of social crisis or an important political decision 4 . In order to be able to „read” the behind-the-scenes intentions, it is important that critical thinking is always sharp, and that "through the set of viewpoints we actively apply in the use of the media, in order to interpret the meaning of the messages we receive" (Potter, 2011: 47), so we can tend and recognize the principles of media literacy.

\subsection{Current Codes of Ethics in context of entertaining contents}

Researching the ethical codes of journalism in European countries, based on data from a specialized website dealing with media ethics (accountablejournalism. org), it has been found that there are currently over 30 national codes of ethics which are in use in Europe. The number of ethical codes is higher than the number of media associations that exist, since in the last six years special codes of ethics have also been adopted concerning the regulation of the online sphere. Most journalists' codes of ethics in Europe were established and enacted in the early 1990s. For the purpose of this paper, and to determine whether there are provisions in the European code relating to entertaining media content, following codes of ethics were analyzed: German, Italian, Dutch, Finnish, Danish, Norwegian and Greek.

With regard to the codes of ethics in the field of journalism in Western European countries, there is a chapter 11 (Ziffer 11 - Sensationsberichterstattung, Jugendschutz ${ }^{5}$ ) in the German code of ethics relating to sensationalist reporting. However, there are no specific provisions in this code concerning regulating entertaining media content. Unlike the German Code of Ethics, the Italian Code of Ethics for Journalists (Carta de Doveri $\left.{ }^{6}\right)$ is significantly poorer. This Code is not precisely categorized and contains only 4 chapters (Introduction, Principles, Duties Sources). None of these chapters mention ethics of entertaining media content. Everything is determined in accordance with writing in the public interest and states accordingly: A journalist has to respect, cultivate and defend the right of information for all people; for these

\footnotetext{
${ }^{4}$ For domestic media theorists, the question of the decision of the City of Nis leadership to give the „Konstantin Veliki“ airport in Nis to the state of Serbia, at the moment of holding the 2018 FIFA World Cup in Russia, at no charge was left opened. Although the citizens of Nis have been outraged and protesting for months about this decision, the Nis Airport Handover Agreement was concluded almost "overnight", at a time when national fever was prevailing around the World Cup in time when Serbia played a key match with Switzerland in advance to pass to further stage of the Competition.

${ }^{5} \mathrm{https}: / /$ www.presserat.de/pressekodex.html

${ }^{6} \mathrm{https}: / /$ accountablejournalism.org/ethics-codes/italy-national-federation-of-the-italian-press-and-nationalcouncil-order-o
} 
reasons he researches and diffuses every piece of information that he considers of public interest in observance of truth and accuracy.

Nor is the Dutch Code of Ethics for Journalists particularly engaging in entertaining media content, although the introduction clearly states the following: The starting point of the Guidelines is that anyone engaged in journalism must take responsibilities for the information he or she distributes and the manner in which he or she operates ${ }^{7}$.

When it comes to Scandinavian countries, the treatment of entertaining media content is not specifically specified in the Finnish and Danish codes of ethics of journalists. The Norwegian Code of Ethics in one part deals with how to treat published information, however, only in the indications. So in Section 4, Section 4.1 states: Make a point of fairness and thoughtfulness in contents and presentation ${ }^{8}$.

Among all the ethical codes of journalists analyzed in European countries, the "poorest" is the Greek code of ethics for journalists. This code has not been amended since its inception in 1988, and contains only 10 items, which generally describe the "mission" of journalists.

\section{Results of the survey on students' attitudes about the ethics of entertainment media contents}

The research on the ethics of entertainment media contents was conducted on a corpus of 98 undergraduate third year students of the Department of Journalism and Communication Studies (90), master students of Communication Science (5) and $\mathrm{PhD}$ students at the Department of "Media and Society" (3), Faculty of Philosophy, University of Niš. The gender structure of the sample is composed of $63 \%$ female and 37\% male respondents. The age included in this survey ranges from 1979 to 1998 year of birth. The time period for conducting the survey was two weeks. The survey is of a combined type with specially designed statements and questions concerning the given research subject, with questions involving independent variables, such as: gender, study program and age. The answers were constructed according to the Likert-type scaling technique.

In Serbia, there is no codified distinction between the ethics of entertainment and informative media; it is universal. However, most of the students partially agree with the following hypothesis: The ethics of entertainment media contents is different from the ethics of informative media (46\%), while $43 \%$ of respondents completely agreed with this hypothesis. (Table 1)

\footnotetext{
${ }^{7}$ https://accountablejournalism.org/ethics-codes/code-of-ethics-netherlands-press-council

${ }^{8} \mathrm{https}$ ://accountablejournalism.org/ethics-codes/Norway-Press
} 
Table 1 Ethics of entertainment media contents

\begin{tabular}{|c|c|c|c|c|c|}
\hline \multirow{2}{*}{$\begin{array}{c}\text { The ethics of entertainment media } \\
\text { contents is different from the ethics of } \\
\text { informative media }\end{array}$} & $\begin{array}{c}\text { I completely } \\
\text { agree }\end{array}$ & $\begin{array}{c}\text { I partially } \\
\text { agree }\end{array}$ & $\begin{array}{c}\text { I am } \\
\text { not } \\
\text { sure }\end{array}$ & $\begin{array}{c}\text { I partially } \\
\text { disagree }\end{array}$ & $\begin{array}{c}\text { I completely } \\
\text { disagree }\end{array}$ \\
\cline { 2 - 6 } & $43 \%$ & $46 \%$ & $1 \%$ & $9 \%$ & $1 \%$ \\
\hline
\end{tabular}

Considering that the aim of entertainment media content and entertainment shows is entertainment and amusement, we wanted to ask future communication scientists, journalists and $\mathrm{PhD}$ students in this field what is their position regarding the ethical treatment of entertainment content. Does it need to be subject to the principles laid down in the Code or is this content exempt from the Code regulations. The hypothesis regarding this was the following: Entertainment content is not subject to ethical assessment because of its nature. The largest number of respondents (41\%) completely disagreed, while $40 \%$ of respondents partially disagreed. (Table 2 )

Table 2 Entertaining contents

\begin{tabular}{|c|c|c|c|c|c|}
\hline \multirow{2}{*}{$\begin{array}{c}\text { Entertainment content is not subject to } \\
\text { ethical assessment because of its } \\
\text { nature }\end{array}$} & $\begin{array}{c}\text { I completely } \\
\text { agree }\end{array}$ & $\begin{array}{c}\text { I partially } \\
\text { agree }\end{array}$ & $\begin{array}{c}\text { I am } \\
\text { not } \\
\text { sure }\end{array}$ & $\begin{array}{c}\text { I partially } \\
\text { disagree }\end{array}$ & $\begin{array}{c}\text { I completely } \\
\text { disagree }\end{array}$ \\
\cline { 2 - 6 } & $3 \%$ & $12 \%$ & $4 \%$ & $40 \%$ & $41 \%$ \\
\hline
\end{tabular}

The psychological and persuasive effect of the media was related to the third hypothesis in the survey. To the hypothesis: Entertainment content can be a bad influence on young people in terms of their behavior, creation of false idols, etc. the highest percentage of respondents answered that they partially agreed (57\%). Twenty six percent $(26 \%)$ of respondents completely agreed, while $16 \%$ of respondents partially disagreed. (Table 3 )

Table 3 Entertainment media content influence

\begin{tabular}{|c|c|c|c|c|c|}
\hline \multirow{2}{*}{$\begin{array}{c}\text { Entertainment content can be a bad } \\
\text { influence on young people in terms of their } \\
\text { behavior, creation of false idols, etc. }\end{array}$} & $\begin{array}{c}\text { I completely } \\
\text { agree }\end{array}$ & $\begin{array}{c}\text { I partially } \\
\text { agree }\end{array}$ & $\begin{array}{c}\text { I am } \\
\text { not } \\
\text { sure }\end{array}$ & $\begin{array}{c}\text { I partially } \\
\text { disagree }\end{array}$ & $\begin{array}{c}\text { I completely } \\
\text { disagree }\end{array}$ \\
\cline { 3 - 6 } & $26 \%$ & $57 \%$ & $1 \%$ & $16 \%$ & $0 \%$ \\
\hline
\end{tabular}

The hypothesis with which we wanted to examine whether the warning about possible insults and contempt of public figures from the world of entertainment and political establishment makes sense, that is, to what extent young people differentiate the actual (informative) program from the creative (entertaining) one, was the following: Young people recognize themselves what is real and what is not in the entertainment media content, and it is not necessary to state that at the beginning, during or at the end of the show. In this regard, the answers were opposing, i.e. partly contradictory and different. Forty one percent (41\%) of respondents partially agreed 
with this hypothesis while $43 \%$ of respondents partially disagreed. (Table 4 )

Table 4 Young people and entertaining media contents

\begin{tabular}{|c|c|c|c|c|c|}
\hline $\begin{array}{c}\text { Young people recognize themselves what is } \\
\text { real and what is not in the entertainment media }\end{array}$ & $\begin{array}{c}\text { I completely } \\
\text { agree }\end{array}$ & $\begin{array}{c}\text { I partially } \\
\text { agree }\end{array}$ & $\begin{array}{c}\text { I am } \\
\text { not } \\
\text { sure }\end{array}$ & $\begin{array}{c}\text { I partially } \\
\text { disagree }\end{array}$ & $\begin{array}{c}\text { I completely } \\
\text { disagree }\end{array}$ \\
\cline { 6 - 7 } $\begin{array}{c}\text { content, and it is not necessary to state that at } \\
\text { the beginning, during or at the end of the show }\end{array}$ & $3 \%$ & $41 \%$ & $5 \%$ & $43 \%$ & $8 \%$ \\
\hline
\end{tabular}

The hypothesis included in the analysis of the Serbian Journalists' Code of Ethics and the AOM Code in the first part of the research regarding the broadcasting time of reality shows was presented to the respondents in the survey. The absolute majority of respondents (95\%) completely agreed with the following statement: Reality show programs should be broadcast late in the evening when children are asleep. (Table 5)

Table 5 Broadcast of reality show program

\begin{tabular}{|c|c|c|c|c|c|}
\hline \multirow{2}{*}{$\begin{array}{c}\text { Reality show programs should be } \\
\text { broadcasted late in the evening when } \\
\text { children are asleep }\end{array}$} & $\begin{array}{c}\text { I completely } \\
\text { agree }\end{array}$ & $\begin{array}{c}\text { I partially } \\
\text { agree }\end{array}$ & $\begin{array}{c}\text { I am } \\
\text { not } \\
\text { sure }\end{array}$ & $\begin{array}{c}\text { I partially } \\
\text { disagree }\end{array}$ & $\begin{array}{c}\text { I completely } \\
\text { disagree }\end{array}$ \\
\cline { 2 - 6 } & $95 \%$ & $5 \%$ & $0 \%$ & $0 \%$ & $0 \%$ \\
\hline
\end{tabular}

The statement with which we wanted to examine how much the respondents pay attention to the violation of ethics when reading or watching entertainment content was the following: We often use entertainment media content in moments of boredom and leisure, and we find it unnecessary to be burdened with ethical issues. Surprisingly or not, the largest number of respondents (54\%) partially disagreed with this statement. However, $24 \%$ of respondents partially agreed with this statement. (Table 6)

Table 6 Use of entertaining media contents

\begin{tabular}{|c|c|c|c|c|c|}
\hline $\begin{array}{c}\text { We often use entertainment media content in } \\
\text { moments of boredom and leisure, and we } \\
\text { find it unnecessary to be burdened with } \\
\text { ethical issues }\end{array}$ & $\begin{array}{c}\text { I completely } \\
\text { agree }\end{array}$ & $\begin{array}{c}\text { I partially } \\
\text { agree }\end{array}$ & $\begin{array}{c}\text { I am } \\
\text { not } \\
\text { sure }\end{array}$ & $\begin{array}{c}\text { I partially } \\
\text { disagree }\end{array}$ & $\begin{array}{c}\text { I completely } \\
\text { disagree }\end{array}$ \\
\cline { 2 - 6 } & $3 \%$ & $24 \%$ & $5 \%$ & $54 \%$ & $14 \%$ \\
\hline
\end{tabular}

To what extent the compatibility of the Code of Ethics with the Public Information Act is useful and how coherent they should be, that is, whether their compliance would contribute to less ethical principles being violated, was touched upon in the following statement: Penalties for violations of ethical principles that are identical with the legal requirements should be increased so that offenses are not repeated. The largest number of respondents (94\%) completely agreed with the above statement. (Table 7) 
Table 7 Ethical principles and legal requirements

\begin{tabular}{|c|c|c|c|c|c|}
\hline \multirow{2}{*}{$\begin{array}{c}\text { Penalties for violations of ethical principles } \\
\text { that are identical with the legal requirements } \\
\text { should be increased so that offenses are not }\end{array}$} & $\begin{array}{c}\text { I completely } \\
\text { agree }\end{array}$ & $\begin{array}{c}\text { I partially } \\
\text { agree }\end{array}$ & $\begin{array}{c}\text { I am } \\
\text { not } \\
\text { repeated }\end{array}$ & $\begin{array}{c}\text { I partially } \\
\text { disagree }\end{array}$ & $\begin{array}{c}\text { I completely } \\
\text { disagree }\end{array}$ \\
\cline { 2 - 6 } $\begin{array}{c}\text { reate } \\
\text { sure }\end{array}$ & $94 \%$ & $6 \%$ & $0 \%$ & $0 \%$ & $0 \%$ \\
\hline
\end{tabular}

Another question regarding the persuasive effects of entertaining media contents was the following: Have you ever felt deceived after watching an entertainment show or reading entertainment content? Most respondents (64\%) said yes, while 33\% said no. (Table 8)

Table 8 Feelings about entertainment content

\begin{tabular}{|c|c|c|c|}
\hline \multirow{2}{*}{$\begin{array}{c}\text { Have you ever felt deceived after watching an entertainment show or rea ding } \\
\text { entertainment content? }\end{array}$} & Yes & No & $\begin{array}{c}\text { I am not } \\
\text { sure }\end{array}$ \\
\cline { 2 - 3 } & $64 \%$ & $33 \%$ & $3 \%$ \\
\hline
\end{tabular}

What respondents think is prevalent in the program schedules of TV channels and in newspaper columns - kitsch and triviality or quality entertainment content, such as TV drama, spoof, sketch or feuilleton - was covered in the statement: I think that there is more trivial entertainment content and kitsch in the media than quality entertainment. Most respondents (93\%) completely agreed. (Table 9)

Table 9 Attitudes about trivial and kitsch entertainment content

\begin{tabular}{|c|c|c|c|c|c|}
\hline $\begin{array}{c}\text { I think that there is more trivial } \\
\text { entertainment content and kitsch in the } \\
\text { media than quality entertainment }\end{array}$ & $\begin{array}{c}\text { I completely } \\
\text { agree }\end{array}$ & $\begin{array}{c}\text { I partially } \\
\text { agree }\end{array}$ & $\begin{array}{c}\text { I am } \\
\text { not } \\
\text { sure }\end{array}$ & $\begin{array}{c}\text { I partially } \\
\text { disagree }\end{array}$ & $\begin{array}{c}\text { I completely } \\
\text { disagree }\end{array}$ \\
\cline { 2 - 6 } & $93 \%$ & $6 \%$ & $1 \%$ & $0 \%$ & $0 \%$ \\
\hline
\end{tabular}

The question which examined what ethical categories are most threatened by the kitsch entertainment content was the following: In your opinion, what ethical values or problems, are most threatened by the kitsch entertainment program? The largest number of respondents (79\%) stated that such programs contribute to the collapse of moral values. (Table 10)

Table 10 Ethical values

\begin{tabular}{|c|c|c|c|c|}
\hline \multirow{2}{*}{$\begin{array}{l}\text { In your opinion, what ethical values or problems are most } \\
\text { threatened by the kitsch entertainment program? }\end{array}$} & Dignity & Truth & Privacy & $\begin{array}{l}\text { Collapse of } \\
\text { moralvalues }\end{array}$ \\
\hline & $6 \%$ & $5 \%$ & $10 \%$ & $79 \%$ \\
\hline
\end{tabular}

\section{Concluding Remarks}

Entertainment media content floods the media, so its impact on the audience is great. We used a survey to examine whether young people pay attention to the 
ethics of such content. It was found by means of the survey that a large percentage ( $81 \%)$ of the target group paid attention to the violation of ethical principles in the entertainment program.

Regarding the persuasive and psychological impact of the entertainment program, which also reflects the suggestive function of the media, the majority of respondents $(83 \%)$ were of the opinion that the media with this type of program could have a bad influence on the behavior of young people, the identification with the stars of that program, and on the creation of false idols. One of the questions concerning the persuasive and psychological impact was about deception, or manipulation by means of entertainment content. This applies in particular to pseudo-satirical shows that are opposed to the real satire (" 24 Minutes with Zoran Kesic" versus the progovernment satire "Kontravizija"). Sixty four percent (64\%) of respondents answered that they felt deceived and manipulated by watching entertainment shows.

When it comes to media literacy and whether young people themselves recognize what is true and what is false in entertainment media contents, the answers of the target group were ambivalent. Forty four percent (44\%) of respondents said that they completely or partially agree that young people distinguish the true picture of reality from the fictitious one, while $51 \%$ of respondents said that they did not agree with the above statement. The control question for this hypothesis was the following: We often use entertainment media content in moments of boredom and leisure, and we find it unnecessary to be burdened with ethical issues. The respondents' answers were consistent with the answers to the first question concerning this segment, as $68 \%$ of respondents completely and partially disagreed with the hypothesis.

As for the "least intelligent" entertainment, the reality show programs and at what time they should be broadcast, the absolute majority of respondents $(100 \%)$ completely and partially agreed that this type of program should be broadcast late in the evening when children are asleep.

Almost one hundred percent (99\%) of the respondents agreed that kitsch and trash prevail over quality entertainment content within the entertainment program, which may also include experimental as well as documentary entertainment shows.

The absolute majority of the surveyed target group also agreed on the compatibility of the principles of ethics with the provisions of the Public Information Act. Thus, $100 \%$ of respondents agreed with the hypothesis that the penalties for violations of ethical principles in certain provisions (violation of privacy, violation of honor, respect of authorship, etc.) should be increased by the Public Information Act in order to make the Code of Ethics more effective.

What respondents rated as "most dangerous" in terms of broadcasting a kitsch entertainment program is the collapse of moral values (79\%), which is not surprising given that in Serbia, nationally broadcast television stations broadcast reality show programs that promote easy money, vulgar vocabulary and "plastic" and unhealthy appearance among women day and night.

Finally, the Serbian audience has somewhat become "immune" to obscene scenes and immoral entertainment. The problem is also psychological in nature, 
which can be described by the term media habituation ${ }^{9}$. Following the example of psychological habituation, we talk about media habituation when the audience is sensitized due to excessive exposure to trivial and tabloid content, so that eventually kitsch, immoral program and media content begin to be taken for granted, without any critical examination or questioning their compliance with ethical principles.

The solution may be the compliance of the Serbian Journalists' Code of Ethics with the Public Information Act, as well as the amendment of certain chapters of the Code; for example, Chapter IV, "Journalists' Responsibilities", where the guidelines should prescribe the time of broadcast of reality shows and unambiguously determine what type of media should include such a program in its program schedule.

It is important to note that the responsibility of journalists in the constant race to survive in the media market has made the journalist's responsibility meaningless and has only become declarative. In such a constellation of forces, where quality media content retreats in the face of a sensationalist style of content processing and infotainmnet principles, the journalistic profession, like journalists, loses its integrity.

It is of particular importance to understand the opinion of Louis Alvin Dey (Dej, 2008) that the media must share moral responsibility for the destruction of democratic values to the extent that the public has given up serious content in exchange for banality. Having in mind the analyzed codes of conduct of European countries, perhaps a victory over banal content can be helped by upgrading the ethical codes of journalism in the section dealing with entertaining media content, by defining and drawing the line between tasty (cultural) and tasteless (non-cultural) entertaining media content.

\section{References}

Babić, J. (2000). Uvod u poslovnu etiku. Prag: Research Support Scheme.

Baraković, V. (2019). Everything Goes - post-moralne perspektive etike medija i novinarstva. Crna Gora, Nikšić: Medijska kultura.

Bernajz, E. (2014). Propaganda-stvaranje javnog mnjenja. Beograd:Ammonite.

Bertran, Ž.K. (2007). Medijska etika i sistemi medijske odgovornosti. Beograd: Original.

Corney, D. (1999). Etika informisanja. Beograd: Clio.

Crnobrnja, S. (2010). Estetika televizije i novih medija. Beograd: Clio.

Cvetanović, I. (2018). Uticaj masovnih medija na stil javnog govora. Niš-Beograd: Talija izdavaštvo i Institut za političke studije.

Dej, L. A. (2008). Etika u medijima. Beograd: Klub Plus.

Gonsalo, H.F. (2012). Filozofija zombija. Beograd: Geopoetika.

Jaccquete D. (2006 ). Journalistic Ethics-Moral Responsabilitiy in the Media. London:Routledge.

\footnotetext{
${ }^{9}$ The term habituation originally comes from psychology. It is referred to as sensitization under the constant influence of some external factor. For example, people who live next to the railroad will after a while stop being bothered by the noise of the rails or the siren of the train. Due to the constant exposure to that noise, they become "immune" and it stops bothering them.
} 
Janićijević, J. (2006). Komunikacija i kultura, sa uvodom u semiotička istraživanja. Sremski Karlovci: Izdavačka knjižarnica Zorana Stojanovića.

Manovič, L. (2001). Metamediji. Beograd: Centar za savremenu umetnost.

Mast, J. (2016) „The Dark Side of Reality TV: Proffesional Ethics and the Treatment of Reality Show Participants" International Journal of Communication, 10, 2179-2200. Available on: https://ijoc.org/index.php/ijoc/article/viewFile/2444/1646 (Accessed April 30, 2020).

Poter, Dž. (2011). Medijska pismenost. Beograd: Clio.

Tjurou, Dž. (2012). Mediji danas: uvod u masovne komunikacije. Beograd: Clio.

Todorović, N. (2006). Tabloidni žurnalizam. Časopis: CM Communication and Media, 1(1), str. 19-31. Available on: http://www.fpn.bg.ac.rs/arhiva/sites/default/files/wpcontent/uploads/CM01.pdf (Accessed April 30, 2020).

\section{Website}

https://accountablejournalism.org/

https://www.presserat.de/

\section{ETIČNOST ZABAVNOG MEDIJSKOG SADRŽAJA}

Rezime. Zabavni medijski sadržaji privlače pažnju mlađe, ali i starije publike. U radu se istražuju etički principi koji se odnose na zabavni medijski sadržaj, sa osvrtom na etički problematične zabavne sadržaje, kao i gde treba povući granicu. U radu je urađena $i$ analiza etičkih kodeksa evropskih zemalja sa ciljem da se ustanovi da li postoje posebne odredbe za zabavni medijski sadržaj. Drugi deo rada prikazuje rezultate ankete sprovedene na Filozofskom fakultetu u Nišu sa ciljem da se ustanovi da li mladi ljudi prepoznaju prekršaje etičkih principa u zabavnom medijskom sadržaju. Takođe, rezultati prikazuju i stavove studenata po pitanju obraćanja pažnje na neetičan sadržaj ovih medija - da li etički prekršaji vređaju njihovo dostojanstvo i da li se osećaju obmanutim.

Ključne reči: etički principi, mediji, studenti, zabavni program, etički kodeks novinara 